\title{
Competitive advantage differences between firms belonging to a business group and independent companies in the Spanish wine industry
}

\author{
Juan Ramón Ferrer-Lorenzo ${ }^{a}$, Silvia Abella-Garcés ${ }^{\mathrm{a}}$ and Teresa Maza-Rubio ${ }^{\mathrm{b}}$
}

\begin{abstract}
A high percentage of companies that compete in the market belong to a business group. This paper analyses the competitive advantages between independent firms and firms belonging to a business group, focusing on the Spanish wine industry. The authors studied 339 wineries, compared their resources and capabilities, the strategies used and their business performance. The results suggest that while resources and capabilities are key for independent firms it is the business strategy that is most important for firms belonging to a business group. The study sheds more light on the application of specific elements to explain a firm's business performance.
\end{abstract}

KEYWORDS: Business group, performance, resource based view, strategy, wine industry.

\section{La diferencia de la ventaja competitiva entre empresas pertenecientes a grupos empresariales y compañías independientes en el sector del vino en España}

RESUMEN: Los grupos empresariales significan un importante porcentaje de empresas que operan en los mercados. Este artículo analiza la diferencia de la ventaja competitiva entre empresas independientes y las que pertenecen a grupos empresariales, en la industria del vino en España. Se han estudiado 339 bodegas, recursos y capacidades, estrategias y rendimiento. Los resultados sugieren que mientras en las empresas independientes los recursos y capacidades son clave, en las empresas que pertenecen a grupos empresariales lo son las estrategias. El estudio arroja más luz sobre los elementos que explican el rendimiento empresarial y la forma en que las empresas los utilizan.

PALABRAS CLAVE: Estrategia, grupos empresariales, resultado, sector del vino, visión basada en recursos.

JEL classification/Clasificación JEL: M10, Q13.

DOI: https://doi.org/10.7201/earn.2017.02.05.

a Dpto. Dirección y Organización de Empresas. Facultad de Empresa y Gestión Pública (Huesca). Universidad de Zaragoza.

b Dpto. Ciencias Agrarias y del Medio Natural. Facultad de Veterinaria (Zaragoza). Universidad de Zaragoza.

Acknowledgements: The authors acknowledge funding from project ECO2013-40935 of the Spanish Ministry of Science and Technology. The second author gratefully acknowledges funding from the FP 7-KBBE-2011-5 Socioec project and funding from the Directorate of Fisheries and Aquaculture of the Basque Government.

Cite as: Ferrer-Lorenzo, J.R., Abella-Garcés, S. \& Maza-Rubio, T. (2017). Competitive advantages differences between firms belonging to a business group and independent companies in the Spanish wine industry. Economía Agraria y Recursos Naturales - Agricultural and Resource Economics, 17(2), 105-132. doi: https://doi. org/10.7201/earn.2017.02.05.

Corresponding author: Juan Ramón Ferrer-Lorenzo. E-mail: jchofer@unizar.es.

Received on July 2017. Accepted on December 2017. 


\section{Introduction}

The country of Spain has the largest surface area of vineyards in the world, with close to one million hectares, this makes it the third largest producer of wine after France and Italy. The wine sector as a whole, since the beginning of the 21 st century, has undergone an important restructuring which has resulted in a general decrease of surface area and a slight increase in production. In 2011, wine production in Spain stood at 33.4 million hectoliters, while in 2016 it reached 37.8 million hectoliters (OIV, 2016). Therefore, the $1 \%$ reduction in the cultivated surface area during the period of 2011 to 2015 (OIV, 2016), was made up for by the restructuring and reorganization of the vineyards and implementing improvements in production and varietal systems, causing an increase in production. The regulation of the European Commission 1308/2013 allows for the increase in the area of cultivation until the year 2020. This could lead Spain in productions that easily exceed 40 million hectoliters per year. If consumption is maintained in Spain, it will lead Spanish wineries to clearly become exporters, around $75 \%$ of the production would have to be sold abroad. This will force Spanish wineries to increase their competitiveness, and to better understand how to operate in the business environment.

One way to deal with competitiveness is to belong to a business group, where companies can feel more protected and with better access to competitive resources. The dilemma of whether to face challenges independently or as part of a group has influenced human behavior since the beginning of time. "It is the business of the very few to be independent; it is a privilege of the strong" (Nietzsche, 2003, p. 99). In the business world, those who do not approach the challenges of the market alone do so instead by creating or joining entities we call the business group (BG). BGs constitute a high percentage of the companies participating in the market. In a study of European companies, Belenzon and Berkovitz (2008) indicate that $52 \%$ are linked to BGs.

In Spain, according to data from the Ministry of Agriculture and Fisheries, Food and Environment (2016), there are 4,052 wine companies. At least $10.5 \%$ of them belong to business groups and nine of the top ten companies in turnover belong to business groups (SABI, June 2016).

Regardless of the economic reasons for their presence, there is no clear winner in the debate over whether membership in a BG results in a better business performance or not. Nonetheless the majority of studies concur that companies belonging to BGs have preferential access to most of the key resources related to organizational performance, including technology, innovation, finance, and distribution (Cai et al., 2016; Choi et al., 2014; Fisman and Khanna 2004; Guillen, 2000). When companies develop their organizational capabilities, they can manage their resources in a way that creates competitive advantage (Kazadi et al., 2016). Thus, BGs with these organizational capabilities could have competitive advantage over independent firms owing to their greater range of resources.

The Resource Based View (RBV) (Barney, 1991) links better business performance and greater firm competitiveness with preferential access to a set of resources and the development of associated capabilities. This study analyzes resources and 
capabilities, business performance (in two different ways: financial and market dimensions), and strategic positioning.

Several studies have analyzed the competitiveness of wine companies from the perspective of resources and capabilities (RBV), or the strategy, both globally (Newton et al., 2015; Galati et al., 2014; Hammervoll et al., 2014; Evaldo Fensterseifer and Rastoin, 2013; Duquesnois et al., 2010), and in Spain (Simon-Elorz et al., 2015; Sellers-Rubio, 2010).

These studies have carried out such analyses through the study of companies in the wine sector regardless of whether or not they are members of a business group. In the present paper, however, authors have analyzed the difference in behavior between groups and companies within the Spanish wine sector, which implies a new approach in the study of competitiveness of this sector, given that no work of this type has been found in the review of the literature.

Another innovative aspect of this paper is that it focuses jointly on resources and capabilities, and strategy, and its effects on business performance, in the Spanish wine sector.

Therefore the main contributions of this study are: first, to present the factors explaining business performance for both independent firms and those belonging to a BG comparatively; second, to make connections between the RBV and strategy as factors explaining competitive advantage, confirming that they are complementary and necessary approaches in taking a global view of a company's performance; and third, to point out that independent companies and companies belonging to BGs have different organizational objectives and therefore perform differently -despite both using capabilities and strategy to strengthen their market position, they do not manage them in the same way.

To study the relationship between resources and capabilities, strategy, and business performance, the authors use the hierarchical regression method ( $\mathrm{Li}$ and Liu, 2014; Ortega, 2010).

The paper is organized as follows: proceeding from this introduction, Section 2 presents the literature review. Section 3 offers a theoretical foundation for six hypotheses, and is followed by a Section 4, sample, variables and model to test the hypotheses. Section 5 reports the results of the analysis and the theoretical and practical implications thereof; Section 6 presents the conclusions drawn from the results. Finally, Section 7 presents the limits and applicability.

\section{Literature Review}

\subsection{Groups}

The literature has traditionally focused on the reasons that explain the existence of BGs and has done this from two perspectives (Cuervo-Cazurra, 2006; Khanna and Palepu, 2000): Economic, based on their role in reducing transaction costs due to market failures (Leff, 1978), and sociological, based on norms of solidarity and 
codes (Granovetter, 1995). The first case (Leff, 1978) foregrounds the emergence, development and expansion of BGs relative to the market failures that can occur in developing economies. These failures occur in the capital market, the product market, the labor market or the technology market, and can also be forced by certain governmental economic policies (Khanna and Palepu, 2000). The difficulty in accessing resources that are essential to their primary economic activity leads firms to expand that activity in order to meet their needs. Examples include Japanese Keiretsu, Korean Chaebols or Latin American Grupos. According to the second approach, which takes a sociological perspective, group affiliation encourages the development of joint activities around a central axis, which is, in many cases, the entrepreneur or family (Cuervo- Cazurra, 2006; Iacobucci and Rosa, 2005; 2010).

But the latest studies on BGs focus more on the reasons for their differentiated performance than on the reasons for their existence. They note that capitalization is an important advantage for their affiliates -fundamentally in times of crisis where BGs replace financial institutions (Belenzon and Berkovitz, 2008)- and that their performance improves when they participate in the capital market (Chittoor et al., 2015). The links between the affiliated company and the parent company are correlated with a better performance: greater linkage facilitates better access to resources, minimizes agency costs and generates higher levels of performance (Mahmood et al., 2017). The advantages resulting from proximity to the company's decision makers and reductions in management costs increase when the property of the group is more concentrated (Singh and Gaur, 2009). The studies also indicate the path that BGs take, affirming that while groups cannot guarantee better performance, they grow by diversifying, exporting, and operating in different industries (Zhang et al., 2016).

\subsection{Competitiveness of a Firm}

There are essentially two schools of thought on competitive advantage. The first focuses on the characteristics of the sector in which the company is situated (Porter, 1980 ) and the second on the individual analysis of each entity with an emphasis on the resources and capabilities available to it (Barney, 1991).

Industry-specific predetermined analysis bases competitive strategy on the determination of a company's positioning within its industry as the source of competitive advantage and corporate profitability (Porter, 1980; 1985).

There are five elements that influence the competitive situation of a given sector (Porter, 1980): These so-called five forces are barriers to entry, suppliers' negotiating power, buyers' negotiating power, substitute products, and the intensity of the rivalry between businesses that compete within a sector. A company will gain a competitive advantage if, by developing a strategy, it is able to find a position from which it can defend itself against the threat these five forces pose, or can influence them in the company's favour. Through strategic planning, the firm can secure its position relative to competitors by building defenses against the five competitive forces, or by seeking positions where the influence of these sources is weaker. There are only two generic strategies to achieve competitive advantage: differentiation and cost. 
Focusing these two strategies on a specific market segment creates a third strategic possibility that opens up a range of four options: differentiation in the whole market or in a segment thereof and low cost in the whole market or in a segment.

In the Resource and Capability Theory (Barney, 1991), the assets available to the company explain its competitive advantage and performance; both can be maintained over time provided that the company can use these assets, preferably without being imitated by its competitors.

Resources are defined as all stocks of available elements controlled by the company (Amit and Schoemaker, 1993). Resources become final products or services through the use of a wide range of other assets and mechanisms available to the company, including technology, information and management systems. Capabilities emerge as the elements that make it achieve the desired effect. Capabilities are information based on tangible or intangible factors or on the company's specific processes and are developed over time based on complex interactions among resources available to the company (Amit and Schoemaker, 1993).

Studies of a company's competitiveness that combine the RBV approach and Porter's (1980) positional strategy have frequently been used to analyze business performance since Spanos and Lioukas (2001) (Chuang and Lin, 2017; Takata, 2016; Rapp et al., 2010; Rivard et al., 2006).

\section{Hypotheses}

\subsection{Technological Capabilities}

The role that technology has played in economic growth cannot be denied (Fagerberg, 1987). Technology refers to a company's ability to perform technical functions, including their ability to develop new products, services and processes that provide competitive advantages (Teece et al., 1997).

The acquisition and use of appropriate technology is essential in a strongly competitive environment (Julien, 1995), creating value in the market for the firm (Gambardella and Giarratana, 2013), and a capacity for development, specialization and competitive advantage (Neill et al., 2014).

However, the wine industry presents a characteristic shared by other agribusiness industries linked to the land - the impossibility of relocating without losing the rights to commercialize their production. Therefore, because they cannot take advantage by themselves of this option to lower their unit costs, they have to maintain efficiency by investing in technology and operational improvements (Ariss et al., 2000).

In the wine sector, technology and its adaptation to changes has proven to be a driver of competitive advantage, so the new producing countries (Australia, Argentina, New Zealand and Chile) have caught up with the traditional producing countries of Europe, through the adoption of new technologies and their application to the sector (Morrison and Rabellotti, 2017). 
Several authors have related technological capabilities with superior performance of the company. For example Welter et al. (2013), focusing on R\&D, found a positive relationship between long-term benefits and technological capability in biotechnology companies. In the industrial sector, Camisón and Villar-López (2014) found a positive relationship between technological innovation capability and the firm's financial and market performance. Also in the industrial sector, Rubio Bañon and Aragón $(2009 ; 2002)$ found positive relationship between the technological position and financial and market performance; and Spanos and Lioukas (2001) found this positive relationship but focused on the existence of an efficient and effective manufacturing department. Finally, in the technological sector, a positive relationship has also been found between high technological capabilities and productivity, market and financial performance, through criteria such as net sales, market capitalization, economic value added, economies of scale and technical experience (Ortega, 2010; Ambastha and Momaya, 2004).

In the case of BGs, they allow access to assets that are otherwise very difficult for individual firms to obtain, such as greater investments in technology, a high level of innovation, and the use of economies of scale and scope (Chittoor et al., 2015), allowing companies belonging to these groups to obtain a superior performance.

This point leads us to formulate our initial hypotheses within the framework of the Spanish wine sector:

Hypothesis 1.1: Technological capabilities are positively related to performance for wineries belonging to BGs.

Hypothesis 1.2: Technological capabilities are positively related to performance for independent wineries.

\subsection{Information and Performance}

Information is a fundamental capability given its connection to knowledge and learning (Stiglitz, 1975; 2014). Information is disseminated and implemented within the organization; it is the basis of collective learning and enriches employees' skills and efficiency. It is also a strong predictor of product innovation and performance as well as a precursor of competitive advantage (Gupta et al., 2009; Owens et al., 1997).

The ability to manage information and information technologies has become a critical resource that provides the basis for gaining competitive advantage and improving market performance (Jensen, 2007; Tippins and Sohi, 2003). Companies that establish better, more agile and more efficient information systems and that can simultaneously internalize information and align it with their own objectives are better positioned to reach higher levels of performance (Mithas et al., 2011).

For the wine sector it is essential to enter new markets and explore new alternatives in already known markets. Therefore, establishing training systems and improving information in the organization, as a means of improving the quality of the services provided, are fundamental practices for the development and maintenance of a sustainable competitive advantage (Gil et al., 2015). 
A number of empirical studies have been conducted confirming that companies that consider the resource of information more broadly, and manage it better by incorporating information technologies, achieve greater performance and competitive advantage over their rivals. For example, in the agri-food industry a positive relationship has been found related to the link between different types of information, such as, a focus on information about consumers, information on strategic planning and making decisions, and information about suppliers and distribution. All these have a positive effect on market and financial performance, giving added value and a return on investments and exports (Carreresi et al., 2011; Mamaqui et al., 2009; Jiménez and Sanz, 2006).

BGs generally have a greater endowment of resources and information capabilities as a result of their development and growth processes, which in many cases stems from their size and the existence of economies of scale (Fisman and Khanna, 2004; Leff, 1978). Consequently, we formulate the following hypotheses:

Hypothesis 2.1: Information and knowledge capabilities are positively related to performance for wineries belonging to BGs.

Hypothesis 2.2: Information and knowledge capabilities are positively related to performance for independent wineries

\subsection{Competitive Strategies and Business Performance}

The company, in an effort to survive and succeed, projects itself externally by defining its strategy, its decisions on which products to offer and in which markets to participate (Rumelt, 1987; Ansoff, 1965). Its values, vision and business mission shape its market position and strategy (Brenes, 2014).

When one speaks of strategy with regard to business, Porter $(1980 ; 1985)$ and the Positioning School clearly maintain supremacy in papers and textbooks (CampbellHunt, 2000). This approach is still used in empirical studies of business strategy and performance (Brenes, 2014; Ortega, 2010; Camisón, 2004; Spanos and Lioukas, 2001; Campbell-Hunt, 2000).

In the case of wine companies, we will evaluate the different kind of strategies: cost, differentiation, and focus on a given segment.

With regard to Porter's strategies in the wine sector, Newton et al. (2015) argue that SMEs tend to be more proactive and have a greater facility to develop new products and markets, focusing on differentiation, where they achieve better financial results than companies that are geared towards costs.

Taking into account the elements that allow for the creation and evolution of BGs, we point out that wineries belonging to them achieve economies of scale and scope, are large, and have a better relationship to market distribution than independent wineries (Vázquez, 2011; Fisman and Khanna 2004; Guillen, 2000; Leff, 1978).

As a result, we propose the following hypotheses: 
Hypothesis 3.1: Independent wineries develop a strategy of differentiation in order to improve their performance.

Hypothesis 3.2: Wineries belonging to BGs develop a cost strategy, taking advantage of the group's economies of scale and better relationships with commercial distributors.

\section{Methodology}

\subsection{Sample}

To carry out the study, a sample of companies has been made from the SABI (System of Analysis of Iberian Balances) database -those under the NACE section 11.02- and the registration of the Denominations of Origin (2015).

From this selection a composite sample was obtained of 3,286 companies, nonetheless and following previous studies of Spanos and Lioukas (2001), the companies with lost data were eliminated. These were companies for which it was not possible to obtain the electronic mail addresses or telephone numbers, as well as those belonging to the same entity, but having different brands and no formal business structure. After this process, the final population size was 2,413 companies. The survey consisted of 12 questions about company situation, 16 questions about resources and capabilities, business environment, strategy and results, and 18 questions about ownership type, business model, billing and financing.

The questionnaire was sent by email, with a telephone reminder a month later to those companies that had not replied. The process lasted four months, from February to May 2016. Finally, 339 valid responses were obtained, representing $14 \%$ of the population, a valid percentage for industrial sectors according to Baruch and Holtom (2008). The sample error was determined from the standard error of the mean, calculated for the case of finite populations; the error committed for a confidence level of $95.5 \%$ and $\mathrm{p}=\mathrm{q}=0.5$ was $5.0 \%$.

Tables 1, 2 and 3 show the data of the companies that have answered and its relation to the whole of the database used.

TABLE 1

Wineries in Spain, According to the Number of Employees (Dec. 2015) and their Percentages, Compared to the Wineries in the Sample

\begin{tabular}{lccccccc}
\hline \multicolumn{2}{l}{ Source and type of company } & Micro $<\mathbf{1 0}$ & $\begin{array}{c}\text { Small } \\
\mathbf{1 0 - 4 9}\end{array}$ & $\begin{array}{c}\text { Medium } \\
\mathbf{5 0 - 2 4 9}\end{array}$ & $\begin{array}{c}\text { SMEs } \\
\mathbf{0 - 2 5 0}\end{array}$ & $\begin{array}{c}\text { Larger than } \\
\mathbf{2 5 0}\end{array}$ & Total \\
\hline \multirow{2}{*}{$\begin{array}{l}\text { SABI } \\
\text { data }\end{array}$} & Number of wineries & 2,019 & 351 & 55 & 2,425 & 4 & 2,429 \\
\cline { 2 - 8 } & $\%$ of total & 83.20 & 14.50 & 2.30 & 99.80 & 0.20 & 100 \\
\hline Survey data, \% of total & 79.20 & 18 & 2.70 & 100 & 0 & 100 \\
\hline
\end{tabular}

Source: Own elaboration. 
In Table 2, the number of wineries that have participated is referenced, according to their membership in the business group. The final result collected in the survey of $7.4 \%$ is in the line of $10 \%$ of the population reviewed in SABI, and therefore is considered representative of it.

Table 3 presents the volume of wine produced by the wineries that have answered the survey and is referenced to the national total and its differentiation between group and independent winery. In the same Table it can be seen that the wineries that have participated in the study contribute to $17 \%$ of the total bottled wine in Spain.

TABLE 2

Answers Received According to the Type of Winery, Belonging to a Business Group or Independent Winery

\begin{tabular}{lcc}
\hline \multicolumn{1}{c}{ Type of winery } & Responses & \% of total \\
\hline Group & 25 & 7.4 \\
\hline Independent winery & 314 & 92.6 \\
\hline
\end{tabular}

Source: Own elaboration.

TABLE 3

Volume of Wine Produced in Spain, and Volume Produced by the Type of Winery According to the Study and its Membership in a Business Group

\begin{tabular}{lcccc}
\hline Type of Winery and Volume & Responses & No Response Given & $\begin{array}{c}\text { Volume in Thousands } \\
\text { of Liters }\end{array}$ & $\begin{array}{c}\text { Percentage } \\
\text { (\%) }\end{array}$ \\
\hline Winery belonging to a group & 23 & 2 & 338,735 & 51.40 \\
\hline Independent winery & 282 & 32 & 319,871 & 48.60 \\
\hline Total responses & 305 & 34 & 658,606 & 100.00 \\
\hline Volume produced in Spain in 2015 (OEMV, 2016) & & $3,770,000$ & 17.47 \\
\hline Percentage of total volume of wine produced by wineries what participated in the study &
\end{tabular}

Source: Own data and OEMV (2016).

\subsection{Variables}

We limit our study to the differentiating factors of competitiveness between independent companies and companies belonging to BGs in the Spanish wine sector. After an extensive literature review, we have designed a survey with subjective data for business performance as well as resources and capabilities, according to $\mathrm{Li}$ and Liu (2014), Ortega (2010), Song et al. (2007), and Spanos and Lioukas (2001). 
The authors have used scales used and validated by previous studies that focused on resources and capabilities, competitive environment, business strategy and performance. In order to verify its applicability to the Spanish wine sector, a subsequent validation of the survey was carried out among entities, experts and managers connected to the industry.

The scale of technological capabilities consists of four indicators assessed with a five-point Likert scale: 1) Efficient and effective production department, 2) technological current equipment and facilities, 3) economies of scale, and 4) advantages in experience. The questions were adapted from Ortega (2010) and Spanos and Lioukas (2001).

The scale of information capabilities consists of ten indicators assessed with a five-point Likert scale: 1) Market information, 2) customer information, 3) information on suppliers, 4) use of information to plan strategy, 5) making contracts and alliances with traditional distributors, 6) creating agreements and alliances with suppliers, 7) information about direct competitors, 8) consumer information, 9) ICT (an information and communications technology), and 10) implementation of agreements and alliances with large distributors. The questions were adapted from Carreresi et al. (2011), Mamaqi et al. (2009) and Jiménez and Sanz (2006). In both, the companies evaluate their position with respect to their competitors and the values of the scale are rated from 1 "much weaker than the competitor" to 5 "much stronger than the competitor".

The scale of business strategy consists of 22 indicators (Robinson and Pearce, 1988) assessed with a five-point Likert scale. Companies evaluate themselves with respect to different business development efforts from 1 "not considered" to 5 "major, constant emphasis". This model was utilized in empirical studies applying the principal component analysis (Ortega, 2010; Camisón et al., 2007; Spanos and Lioukas, 2001; among others), as in our case. There are 22 topics that Robinson and Pearce (1988) enumerate, adapted to the reality of the wine sector after conferring with experts.

The performance scale consists of seven indicators assessed with a five-point Likert scale: 1) Sales volume in $€, 2)$ growth in sales volume in $€, 3)$ market share $(\%), 4)$ growth in market share, 5) net profits, 6) profit margin, and 7) return on own capital. The questions were adapted from Spanos and Lioukas (2001) and Ortega (2010), where companies evaluate their position with respect to their competitors in terms of market position and profitability in the last three years, and where the values of the scale are from 1 "far below the competitor" to 5 "far above the competitor".

\subsection{Model}

The model that is going to be developed tries to test the six hypotheses. In other words, whether or not technological and information capabilities explain the business performance, both for the wineries belonging to the business groups and for the independent ones. And whether or not strategic orientation can explain why the business performance is different for groups, as can be seen in cost orientation, than it is for independents, as can be seen with differentiation. 
In order to determine the relationships between resources and capabilities, the strategy used by the company, and business performance, we will use the hierarchical regression method (Li and Liu, 2014; Ortega, 2010; Rubio Bañón and Aragón, 2009). In the first stage, the analysis is determined for the wineries belonging to BGs, and then, for the independent wineries.

\subsubsection{Dependent Variable}

The dependent variable is business performance. The objective of this paper is to test if business performance is determined by technological capabilities, information capabilities and strategic positioning, and at the same time, the variation in performance when the company does or does not belong to a BG.

As in the previous literature evaluating the global importance of each dimension, a factor analysis has been carried out, extracting a component that determines how each company conceives of its performance. The extracted factor explains $66.78 \%$ of the variance, with a $\mathrm{KMO}=0.84$, and Cronbach's alpha $=0.917$, as Table 4 illustrates.

TABLE 4

Factor Analysis: Business Performance

\begin{tabular}{lccc}
\hline \multicolumn{1}{c}{ Variables } & Alpha without item & Component & Communality \\
\hline Profitability. Net profits & 0.902 & 0.836 & 0.698 \\
\hline Market position. Sales volume $€$ & 0.903 & 0.828 & 0.686 \\
\hline Market position. Market share \% & 0.904 & 0.820 & 0.672 \\
\hline Market position. Growth in market share & 0.903 & 0.820 & 0.672 \\
\hline Market position. Growth in sales volume $€$ & 0.905 & 0.813 & 0.661 \\
\hline Profitability. Profit margin & 0.906 & 0.807 & 0.652 \\
\hline Profitability. Return on own capital & 0.908 & 0.796 & 0.634 \\
\hline Cronbach alpha of the whole scale & 0.917 & & \\
\hline \% Total explained variance & 66.783 & & \\
\hline K.M.O. & 0.840 & & \\
\hline & gl & 2020.509 & \\
\cline { 2 - 4 } Barlett Test: & sig & 0.000 & \\
\cline { 2 - 4 }
\end{tabular}

Source: Own elaboration. 


\subsubsection{Independent Variables}

Technological capabilities, information capabilities and competitive strategies have been set as independent variables.

- Technological Capabilities

The four indicators have been reduced using the factor analysis methodology. In this case, we ended up with one factor that accounts for $57.9 \%$ of the variance, KMO of 0.71 , and Cronbach's alpha $=0.751$, as Table 5 illustrates.

TABLE 5

Factor Analysis: Technological Capabilities

\begin{tabular}{lccc}
\hline \multicolumn{1}{c}{ Variables } & Alpha without item & Component & Communality \\
\hline Efficient and effective production department & 0.613 & 0.864 & 0.746 \\
\hline Current technological equipment and facilities & 0.709 & 0.741 & 0.549 \\
\hline Economies of scale & 0.715 & 0.725 & 0.525 \\
\hline Advantages in experience & 0.728 & 0.704 & 0.496 \\
\hline Cronbach alpha of the whole scale & 0.751 & & \\
\hline \% Total explained variance & 57.914 & & \\
\hline K.M.O. & 0.713 & & \\
\hline & $\chi^{2}$ & 339.887 & \\
\cline { 2 - 4 } Barlett Test: & $\mathrm{gl}$ & 600 \\
\hline
\end{tabular}

Source: Own elaboration.

- Information Capabilities

As in the previous case, the ten indicators used to measure this variable have been reduced using factor analysis methodology, obtaining a single factor that explains $59.3 \%$ of the variance, with a KMO of 0.91 , and Cronbach's alpha $=0.921$, as Table 6 illustrates. 
TABLE 6

Factor Analysis: Information Capabilities

\begin{tabular}{|c|c|c|c|}
\hline Variables & Alpha without item & Component & Communality \\
\hline Market information & 0.908 & 0.835 & 0.698 \\
\hline Customer information & 0.909 & 0.830 & 0.689 \\
\hline Information on suppliers & 0.910 & 0.816 & 0.665 \\
\hline Use of information to plan strategy & 0.911 & 0.795 & 0.633 \\
\hline $\begin{array}{l}\text { Making contracts and alliances with traditional } \\
\text { distributors }\end{array}$ & 0.911 & 0.773 & 0.598 \\
\hline Creating agreements and alliances with suppliers & 0.912 & 0.766 & 0.586 \\
\hline Information about direct competitors & 0.914 & 0.755 & 0.570 \\
\hline Consumer information & 0.914 & 0.750 & 0.563 \\
\hline $\begin{array}{l}\text { ICT (an information and communications } \\
\text { technology) }\end{array}$ & 0.917 & 0.697 & 0.486 \\
\hline $\begin{array}{l}\text { Implementation of agreements and alliances with } \\
\text { large distributors }\end{array}$ & 0.919 & 0.671 & 0.451 \\
\hline Cronbach alpha of the whole scale & 0.921 & & 0.921 \\
\hline$\%$ Total explained variance & 59.372 & & 59.372 \\
\hline K.M.O. & 0.915 & & 0.915 \\
\hline \multirow{3}{*}{ Barlett Test: } & $x^{2}$ & 1989.251 & \\
\hline & $\mathrm{gl}$ & 45 & \\
\hline & sig & 0.000 & \\
\hline
\end{tabular}

Source: Own elaboration.

- Competitive Strategies

One of the models most commonly used to try to capture the typology of business strategy is the scale proposed by Robinson and Pearce (1988), and used by Ortega (2010), Camisón et al. (2007), Simon and Marqués (2005) and Spanos and Lioukas (2001), among others. The scale, developed in 1988, aims to expand the generic strategies of Porter and Strategy (1980) by facilitating their characterization in the empirical terms of business studies. Five components have been extracted: efficiency, marketing, innovation and development of new products, costs, and segmentation. As a whole, these explain $60.66 \%$ of the variance. The results of the different reliability statistics show values within the limits of acceptability, Cronbach's alpha $=0.875$ and $\mathrm{KMO}=0.862$, as Table 7 illustrates. 


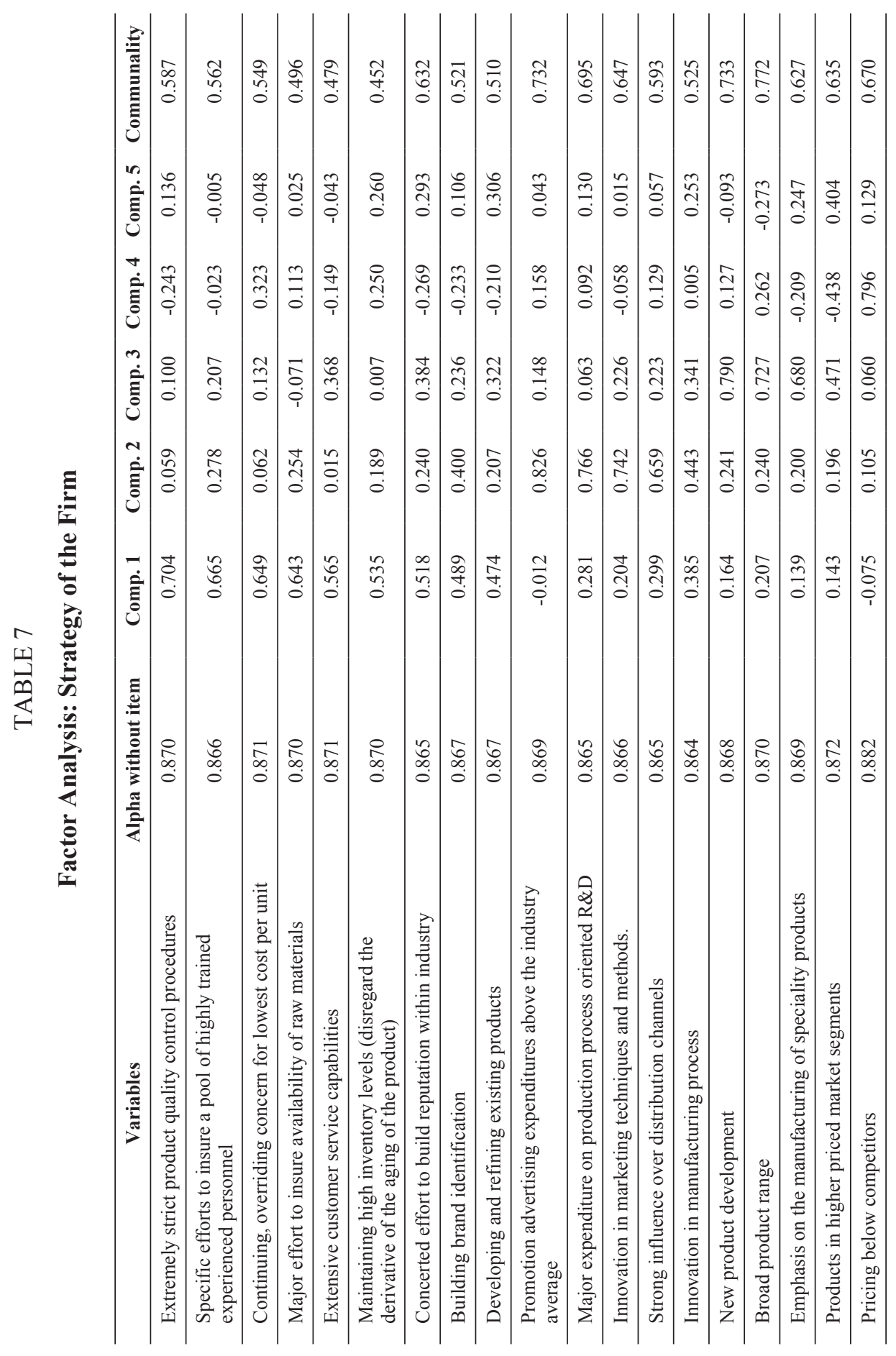




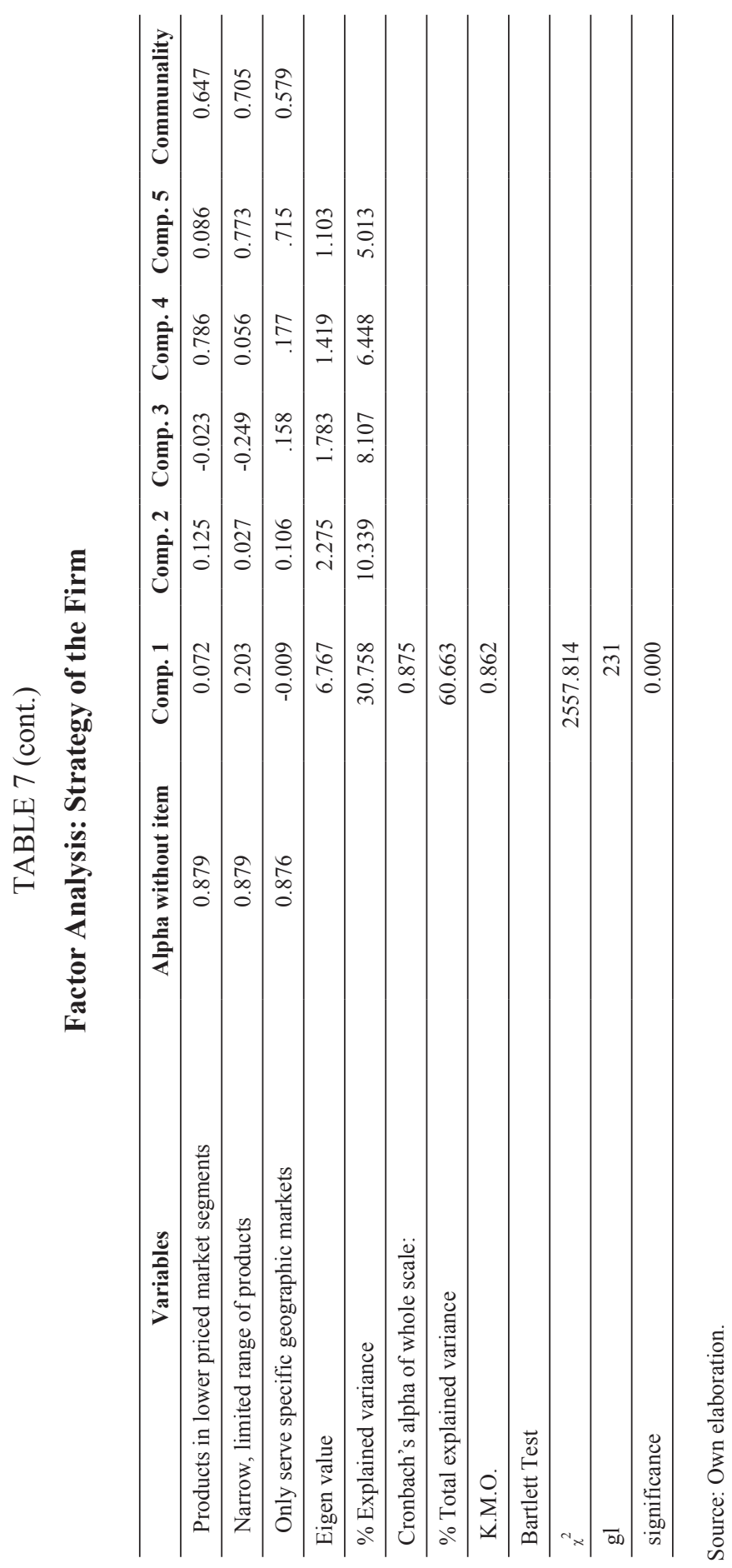


- $\quad$ Efficiency Strategy

Nine indicators of the twenty-two defined by Robinson and Pearce (1988) are part of this first extracted component and explain $30.76 \%$ of the variance. This component encompasses the factors that lead the company to take extreme care with the products offered to the customer and ensure implementation of efficient processes.

- $\quad$ Marketing Strategy

In this second component, we cite five test indicators that explain $10.34 \%$ of the variance. In these areas, business executives demonstrate their concern for and inclination toward the control of different marketing techniques as a strategy to achieve their business goals.

- Development of New Products Strategy

This extracted component explains $8.10 \%$ of the variance and consists of four test indicators: development of new products, a wide range of products, emphasis on special products and high price segment products.

- Orientation at Low Price Strategy

This factor can be extracted via two indicators with a total explained variance of $6.45 \%$. This indicates a clear orientation toward offering products of lesser perceived benefit, lower price relative to competitors.

- Differentiation through Market and Product Specificity Strategy

This component refers to those companies that choose to compete through a strategy of targeting very few products to a very specific market segment more oriented toward high prices. The total variance explained in this case is $5.01 \%$.

\subsubsection{Control Variables}

Numerous studies refer to the influence that elements such as the size of the company and degree of rivalry can have on performance. For this reason, the majority of the studies incorporate control variables that help to understand business performance (Ortega, 2010; Rubio Bañón and Aragón, 2002). In this study, we measured company size in terms of assets with seven categories with values ranging from less than 400 thousand euros to more than 20 million euros. Rivalry level measures were taken according to the scale used by Spanos and Lioukas (2001) and Ortega (2010). On this issue, the manager of the company evaluates competition levels using a fivepoint Likert scale addressing product features, promotional strategies, access to distribution channels and customer service strategy. The variable was extracted through factorial analysis, a factor that explains $69.2 \%$ of the variance with a KMO of 0.80 and Cronbach's alpha of 0.85 , as Table 8 illustrates. 


\section{TABLE 8}

\section{Factor Analysis: Internal Rivalry}

\begin{tabular}{lccc}
\hline \multicolumn{1}{c}{ Variables } & Alpha without item & Component & Communality \\
\hline Promotional strategies among rivals & 0.785 & 0.874 & 0.768 \\
\hline Service strategies to customers & 0.808 & 0.843 & 0.711 \\
\hline Access to distribution channels & 0.812 & 0.839 & 0.709 \\
\hline Product characteristics & 0.846 & 0.769 & 0.599 \\
\hline Cronbach alpha of the whole scale & 0.850 & & \\
\hline \% Total explained variance & 69.266 & & \\
\hline K.M.O. & 0.805 & & \\
\hline & $x^{2}$ & 574.787 & \\
Barlett Test: & $\mathrm{gl}$ & 6 & \\
\cline { 2 - 5 } & $\mathrm{sig}$ & .000 & \\
\cline { 2 - 4 } & &
\end{tabular}

Source: Own elaboration.

\subsubsection{Proposed Model}

In order to test for the suggested hypothesis, this paper proposes the following model:

$Y j=\beta 0+\beta 1 C r j+\beta 2 C a j+\beta 3 E e j+\beta 4 E m j+\beta 5 E p j+\beta 6 E b j+\beta 7 E s j+\beta 8 R t j+\beta 9 R m j+e i$

where $Y j$ is the performance value for firm " $\mathrm{j}$ "; $\beta 0$ the constant of the function or its cut-off with the origin of coordinates. $\beta 1$ and $\beta 2$ are the coefficients of the control variables: internal rivalry $(\mathrm{Cr})$ and assets $(\mathrm{Ca}) . \beta 3, \beta 4, \beta 5, \beta 6, \beta 7$ are the coefficients of the competitive variables of the companies: efficiency $(\mathrm{Ee})$, marketing $(\mathrm{Em})$, new products $(E p)$, low price $(E b)$ and segment specificity $(E s) . \beta 8$ and $\beta 9$ are the coefficients of the company's resources and capabilities, both technological (Rt) and information-based $(R m)$. Finally, ei is the error or residue of the proposed model.

A hierarchical regression methodology has been used in order to test for the hypothesis (Hair et al., 2009, p. 172) using the statistics package SSPS v20.

The variables chosen to construct the multivariable linear correlation appear in Table 9, with mean values, standard deviation and correlation matrix. The study evaluates the possible multicollinearity between the variables through FIV and condition index; in both cases, the values are lower than ten as recommended by the literature (Hair et al., 2009, p. 209). 


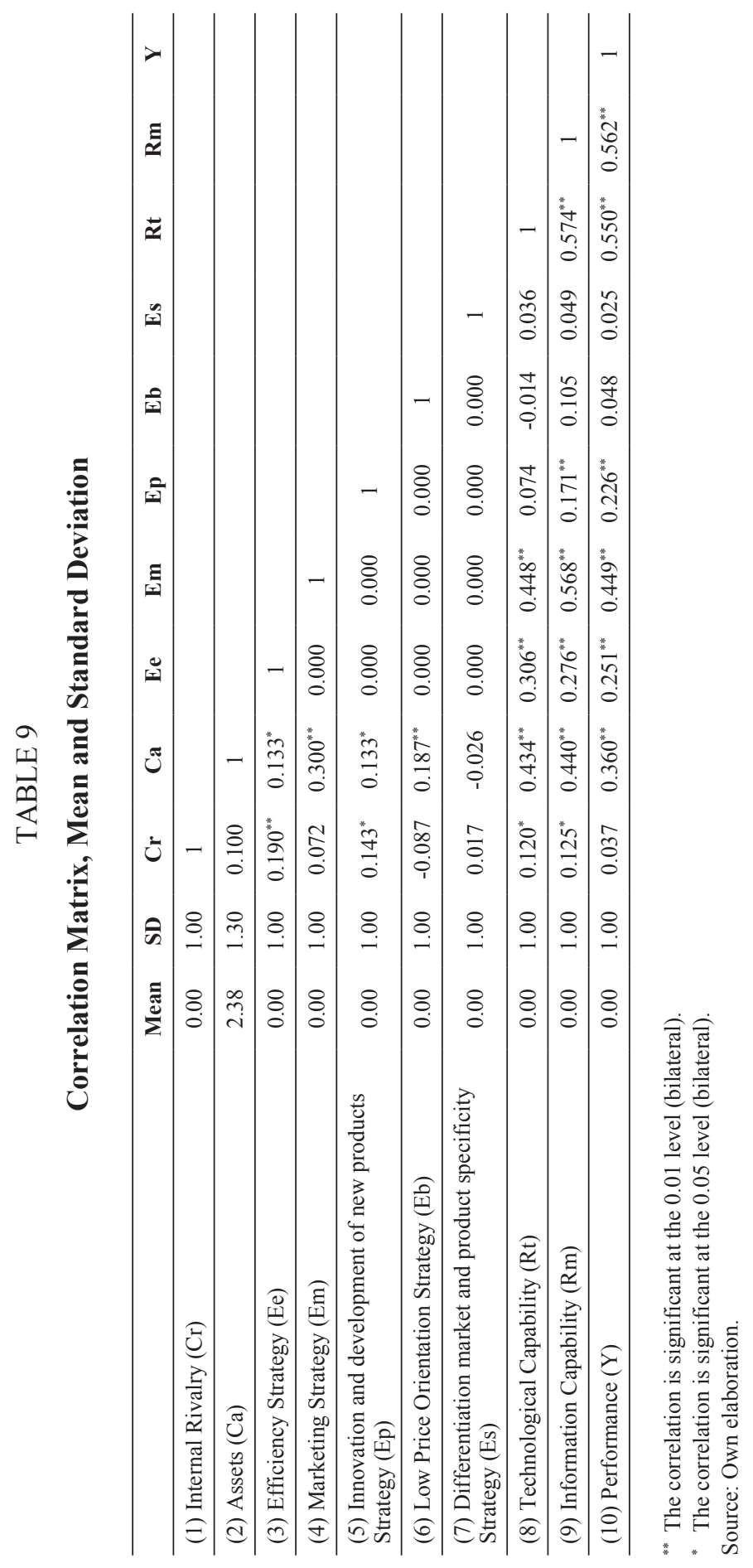




\section{Results}

This paper analyzed wineries that belong to a group, introducing control variables, then strategy variables, and finally, technological and information capabilities. The process was repeated for independent wineries. Tables 10 to 12 show the results of the tested model.

The values of adjusted $\mathrm{R}^{2}$ and regression coefficients, are in line with similar studies (Ortega, 2010; Rubio Bañón and Aragón, 2009) and indicate that the built model has enough elements to suggest a series of compelling conclusions.

\subsection{Model with Wineries Belonging to BGs}

As Table 10 illustrates, the full model reaches an adjusted $\mathrm{R}^{2}$ of 0.539 , and in it, the Technological Capability $(\beta=0.725 ; \mathrm{p}<0,05)$ is the most important component. In strategic variables Marketing Strategy $(\beta=0.491 ; p<0.2)$ and Efficiency Strategy $(\beta=0.468 ; p<0.2)$ maintain the greatest weight. The results partially corroborate the hypotheses. Hypothesis 1.1 and 3.2 are confirmed, but we have to reject hypothesis 2.1 and therefore state that information capabilities do not have a positive effect on higher performance.

TABLE 10

Regression Analysis for Wineries Belonging to Groups

\begin{tabular}{|c|c|c|c|c|c|c|}
\hline \multirow[b]{3}{*}{ Variables } & \multicolumn{6}{|c|}{ MODEL FOR WINERIES BELONGING TO A GROUP } \\
\hline & \multicolumn{2}{|c|}{ Control Variable Model } & \multicolumn{2}{|c|}{$\begin{array}{c}\text { Control Variable Model } \\
+ \text { Strategy }\end{array}$} & \multicolumn{2}{|c|}{ Full Model } \\
\hline & $\beta$ & Student's T-test & $\beta$ & Student's T-test & $\boldsymbol{\beta}$ & Student's T-test \\
\hline (1) Internal Rivalry & 0.566 & $3.097^{* * *}$ & 0.335 & 1.332 & 0.372 & $1.670^{\wedge}$ \\
\hline (2) Assets & 0.302 & $1.652^{\wedge}$ & 0.344 & $1.728^{\wedge}$ & 0.010 & 0.041 \\
\hline (3) Efficiency Strategy & & & 0.578 & $1.782^{\wedge}$ & 0.468 & $1.554^{\wedge}$ \\
\hline (4) Marketing Strategy & & & 0.400 & 1.226 & 0.491 & $1.405^{\wedge}$ \\
\hline $\begin{array}{l}\text { (5) Innovation and Develop- } \\
\text { ment of New Products Strategy }\end{array}$ & & & 0.134 & 0.554 & 0.177 & 0.730 \\
\hline $\begin{array}{l}\text { (6) Low Price Orientation } \\
\text { Strategy }\end{array}$ & & & 0.051 & 0.180 & 0.239 & 0.904 \\
\hline $\begin{array}{l}\text { (7) Differentiation Market and } \\
\text { Product Specificity Strategy }\end{array}$ & & & 0.164 & 0.721 & 0.299 & 1.396 \\
\hline (8) Technological Capability & & & & & 0.725 & $2.347^{* *}$ \\
\hline (9) Information Capability & & & & & -0.268 & -0.955 \\
\hline $\mathrm{R}^{2}$ & & 0.434 & & 0.624 & & 0.758 \\
\hline Adjusted $\mathrm{R}^{2}$ & & 0.367 & & 0.405 & & 0.539 \\
\hline Change in $\mathrm{R}^{2}$ & & 0.367 & & 0.038 & & 0.134 \\
\hline
\end{tabular}

${ }^{* * * * *} \mathrm{p}<0.001 ;{ }^{* * *} \mathrm{p}<0.01 ;{ }^{* *} \mathrm{p}<0.05 ;{ }^{*} \mathrm{p}<0.1 ;{ }^{\wedge} \mathrm{p}<0.2$

Source: Own elaboration. 


\subsection{Model with Independent Wineries}

As Table 11 illustrates, the full model reaches an adjusted $\mathrm{R}^{2}$ of 0.447 , and in it, a change occurs in favor of the resources Technological Capability $(\beta=0.348 ; p<$ $0.001)$ and Information Capability $(\beta=0.243 ; p<0.01)$ that present higher beta values. In strategy both are practically equal with Innovation Strategy $(\beta=0.163 ; p<$ $0.05)$ and Marketing Strategy $(\beta=0.181 ; p<0.05)$.

The results corroborate the initial hypothesis for independent wineries, as both hypothesis 1.2 and 2.2 are accepted: information and technological capabilities explain business performance. Hypothesis 3.1 is also accepted, meaning that an orientation toward Differentiation Strategy and New Products Strategy is an explanatory element of business performance.

TABLE 11

\section{Regression Analysis for Independent Wineries}

\begin{tabular}{|c|c|c|c|c|c|c|}
\hline \multirow[b]{3}{*}{ Variables } & \multicolumn{6}{|c|}{ MODEL FOR INDEPENDENT WINERIES } \\
\hline & \multicolumn{2}{|c|}{ Control Variable Model } & \multicolumn{2}{|c|}{$\begin{array}{c}\text { Control Variable Model } \\
+ \text { Strategy }\end{array}$} & \multicolumn{2}{|c|}{ Full Model } \\
\hline & $\boldsymbol{\beta}$ & Student's T-test & $\boldsymbol{\beta}$ & Student's T-test & $\boldsymbol{\beta}$ & Student's T-test \\
\hline (1) Internal Rivalry & -0.039 & -0.659 & -0.091 & $-1.579^{\wedge}$ & -0.129 & $-2.463^{\wedge}$ \\
\hline (2) Assets & 0.336 & $5.669^{* * * *}$ & 0.156 & $2.591^{\wedge}$ & 0.000 & -0.003 \\
\hline (3) Efficiency Strategy & & & 0.217 & $3.782^{* * * *}$ & 0.060 & 1.103 \\
\hline (4) Marketing Strategy & & & 0.420 & $7.160^{* * * *}$ & 0.181 & $2.831^{* *}$ \\
\hline $\begin{array}{l}\text { (5) Innovation and } \\
\text { Development of New } \\
\text { Products Strategy }\end{array}$ & & & 0.192 & $3.388^{* * *}$ & 0.163 & $3.142^{* *}$ \\
\hline $\begin{array}{l}\text { (6) Low Price Orientation } \\
\text { Strategy }\end{array}$ & & & 0.031 & 0.540 & 0.035 & 0.658 \\
\hline $\begin{array}{l}\text { (7) Differentiation Market } \\
\text { and Product Specificity } \\
\text { Strategy }\end{array}$ & & & 0.041 & 0.738 & 0.026 & 0.516 \\
\hline $\begin{array}{l}\text { (8) Technological } \\
\text { Capability }\end{array}$ & & & & & 0.348 & $5.230^{* * * *}$ \\
\hline (9) Information Capability & & & & & 0.243 & $3.329^{* * *}$ \\
\hline $\mathrm{R}^{2}$ & & 0.112 & & 0.324 & & 0.471 \\
\hline Adjusted $\mathrm{R}^{2}$ & & 0.105 & & 0.302 & & 0.447 \\
\hline Change in $\mathrm{R}^{2}$ & & 0.105 & & 0.197 & & 0.145 \\
\hline
\end{tabular}

${ }^{* * * * *} \mathrm{p}<0.001 ;{ }^{* * *} \mathrm{p}<0.01 ;{ }^{* *} \mathrm{p}<0.05 ;{ }^{*} \mathrm{p}<0.1 ; \wedge \mathrm{p}<0.2$.

Source: Own elaboration. 
The differential analysis between wineries belonging to groups and independent wineries presents interesting conclusions, as indicated in Table 12. Among the control variables, Internal Rivalry is positively correlated to performance for groups and negatively for independent wineries. With respect to strategic elements, Marketing Strategy is the element that is present in explaining the results for both groups and independent wineries. Next, the Efficiency Strategy prevails among the groups, and the New Products strategy for independent wineries. In terms of resources and capabilities, in independent wineries there is a positive relationship between both and performance, with technological capabilities being the most relevant. The technological capabilities are more important for groups than for independent wineries. However the information capability is scarcely relevant for groups and very relevant for independent wineries.

TABLE 12

\section{$\beta$ and Student's T-test Data between Wineries Belonging to a Group and Independent Wineries}

\begin{tabular}{lcccc}
\hline \multirow{2}{*}{ Variables } & \multicolumn{2}{c}{ Wineries Belonging to a Group } & \multicolumn{2}{c}{ Independent Wineries } \\
\cline { 2 - 5 } & $\boldsymbol{\beta}$ & Student's T-test & $\boldsymbol{\beta}$ & Student's T-test \\
\hline (1) Internal Rivalry & 0.372 & $1.670^{\wedge}$ & -0.129 & $-2.463^{\wedge}$ \\
\hline (2) Assets & 0.010 & 0.041 & 0.000 & -0.003 \\
\hline (3) Efficiency Strategy & 0.468 & $1.554^{\wedge}$ & 0.060 & 1.103 \\
\hline (4) Marketing Strategy & 0.491 & $1.405^{\wedge}$ & 0.181 & $2.831^{* *}$ \\
\hline $\begin{array}{l}\text { (5) Innovation and Development of New } \\
\text { Products Strategy }\end{array}$ & 0.177 & 0.730 & 0.163 & $3.142^{* *}$ \\
\hline (6) Low Price Orientation Strategy & 0.239 & 0.904 & 0.035 & 0.658 \\
\hline $\begin{array}{l}\text { (7) Differentiation Market and Product } \\
\text { Specificity Strategy }\end{array}$ & 0.299 & 1.396 & 0.026 & 0.516 \\
\hline (8) Technological Capability & 0.725 & $2.347^{* *}$ & 0.348 & $5.230^{* * * *}$ \\
\hline (9) Information Capability & -0.268 & -0.955 & 0.243 & $3.329^{* * *}$ \\
\hline
\end{tabular}

${ }^{* * * * *} \mathrm{p}<0.001 ;{ }^{* * *} \mathrm{p}<0.01 ;{ }^{* *} \mathrm{p}<0.05 ;{ }^{*} \mathrm{p}<0.1 ;{ }^{\wedge} \mathrm{p}<0.2$.

Source: Own elaboration.

\section{Conclusions}

The results of the study show that resources, capabilities and strategy are compatible (Spanos and Lioukas, 2001) and explain business performance while simultaneously revealing that resources and capabilities influence strategies (Barney, 2011; Rumelt, 1987), or that strategies are chosen based on the resources the company controls (Barney et al., 2011). This idea is evidenced through the positive correlation between Information Capability and Marketing Strategy, or between Efficiency and Marketing Strategies and Technology Capabilities. This correlation offers 
evidence that businesses orient their strategy in one direction or another depending on the resources they control, and that they in turn develop their resources and capabilities based on these strategies (Barney et al., 2011). These results would be in line with the concept of strategy formation defined by Barney et al. (2011) when considering the same ability to implement the strategy as a resource capable of providing a sustainable strategy advantage.

Regarding the difference between groups and independent wineries, the conclusions of the study seem to indicate that groups compete mainly in Marketing and Efficiency and strategies are more important than resources and capabilities. Overall, the strategic factors that explain business performance present a complex picture because all forms of competition seem to lead to a positive result, though to varying degrees. However, the efficiency factor is important for groups, but not for independent wineries, suggesting that groups focus mainly on controlling factors of production, which are highly correlated with a cost orientation based on Porter's model (Suarez, 1994). Competing in marketing is the predominant strategy for both types of wineries. Conversely, the results of independent wineries are better explained by resources and capabilities than by strategic positioning. The endowment of resources is a fundamental element when it comes to competing, supporting the general idea that independent wineries have less availability of resources. This compels independent wineries to situate themselves in market segments with higher added value where they can mask lower efficiency, making the New Products Strategy more important than the Efficiency Strategy.

Among BGs, Technological Capability explains the performance but information capability does not have any importance in explaining the result. Resources must be scarce, relevant, durable, non-transferable and non-replicable in order to obtain a competitive advantage (Grant, 2010), and in this case it does not seem that these conditions are met in Information Capability. On the other hand, independent wineries, being smaller and free from the urgent need to maintain large structures and therefore sell large quantities, can reject sales in large-scale distribution, directing their marketing strategies toward new products and greater differentiation. In this case, resources are important because they are not available to all companies (Cai et al., 2016), which hinders the existence of state-of-the-art technology and blocks the efficiency with which the company can compete in independent wineries. Due to their smaller structure, the information flow is slower, turning information capabilities into a key resource that facilitates better performance and compensates for its greater difficulty in accessing the market (Guillen, 2000).

\section{Limitations of the study and applicability}

This paper analyzes how resources and capabilities interact with business strategies and how both explain business performance. The analysis has focused on the wine sector and has examined whether the situation, performance and importance differ according to whether the winery belongs to a $\mathrm{BG}$ or functions independently. The results show that RBV and strategic positioning do explain business results, 
confirming previous studies (Ortega, 2010; Spanos and Lioukas, 2001). Whether resources and capabilities or strategy are more important depends on whether the winery is independent or belongs to a BG. The relation between group and size still remains to be studied in future works. Although in our study we have taken the volume of assets as a control variable that was not explanatory, some authors (Bamiatzi et al., 2014; Iacobucci and Rosa, 2005) consider group size and growth to reflect a single reality that results from a business development process. It is impossible to not mention the crisis conditions that have shaken Western Europe since 2008, which have especially limited financing opportunities. A lack of financing limits the resources available to the company -technology, information systems, and others- placing greater stress on resources and capabilities to explain business performance. It is necessary to point out that members of BGs have greater facility in financing given the possibility of appealing to the group. When financing is not a limiting resource, business strategy has greater importance in achieving business objectives. Another limitation is the sample size: in spite of representing the reality of the sector, in terms of percentages of companies belonging to groups and independent wineries, a more extensive survey would have permitted better statistical parameters.

Examining the factors of competitiveness, this study does not determine which of the two - strategic position - provides a better explanation of business performance, and research remains open on this issue.

\section{References}

Ambastha, A. \& Momaya, K. (2004). "Challenges for Indian software firms to sustain their global competitiveness". Singapore Management Review, 26(2), 65.

Amit, R. \& Schoemaker, P. J. (1993). "Strategic assets and organizational rent". Strategic Management Journal, 14(1), 33-46.

Ariss, S.S., Raghunathan, T.S. \& Kunnathar, A. (2000). "Factors affecting the adoption of advanced manufacturing technology in small firms". SAM Advanced Management Journal, 65(2), 14.

Ansoff, H.I. (1965).Corporate strategy: An analytic approach to business policy for growth and expansion. New York: McGraw-Hill.

Bamiatzi, V., Cavusgil, S.T., Jabbour, L. \& Sinkovics, R.R. (2014). "Does business group affiliation help firms achieve superior performance during industrial downturns? An empirical examination”. International Business Review, 23(1), 195 211. https://doi.org/10.1016/j.ibusrev.2013.04.003.

Barney, J. (1991). "Firm resources and sustained competitive advantage". Journal of Management, 17(1), 99-120.

Barney, J.B., Ketchen, D.J. \& Wright, M. (2011). "The future of resource-based theory revitalization or decline?” Journal of Management, 37(5), 1299-1315.

Baruch, Y. \& Holtom, B.C. (2008). "Survey response rate levels and trends in organizational research". Human Relations, 61(8), 1139-1160. http://dx.doi. org/10.1177/0018726708094863. 
Belenzon, S. \& Berkovitz, T. (2010). "Innovation in business groups". Management Science, 56(3), 519-535. https://doi.org/10.2139/ssrn.1026110 - Source: RePEc.

Brenes, E.R., Montoya, D. \& Ciravegna, L. (2014). "Differentiation strategies in emerging markets: The case of Latin American agribusinesses". Journal of Business Research, 67(5), 847-855. https://doi.org/10.1016/j.jbusres.2013.07.003.

Cai, W., Zeng, C.C., Lee, E. \& Ozkan, N. (2016). "Do business groups affect corporate cash holdings? Evidence from a transition economy". China Journal of Accounting Research, 9(1), 1-24. https://doi.org/10.1016/j.cjar.2015.10.002.

Camisón, C. (2004). "Shared, competitive, and comparative advantages: a competence-based view of industrial-district competitiveness". Environment and Planning $A, 36(12), 2227-2256$.

Camisón, C. \& Villar-López, A. (2014). “Organizational innovation as an enabler of technological innovation capabilities and firm performance". Journal of Business Research, 67(1), 2891-2902. https://doi.org/10.1016/j.jbusres.2012.06.004.

Camisón, C., Simón, F.G. \& Marqués, D.P. (2007). "Estrategias competitivas y desempeño empresarial: estudio comparativo de los modelos de Robinson \& Pearce y Miles \& Snow en el sector hotelero español". Investigaciones Europeas de Dirección y Economía de la Empresa, 13(3), 161-182.

Campbell-Hunt, C. (2000). "What have we learned about generic competitive strategy? A meta-analysis". Strategic Management Journal, 21(2), 127-154.

Carraresi, L., Mamaqi, X., Albisu Aguado, L.M. \& Banterle, A. (2011). "The relationship between strategic choices and performance in Italian food SMEs: A resource-based approach". Communication to the XIII th Congress of the European Association of Agricultural Economists, Zurich, Switzerland.

Chittoor, R., Kale, P. \& Puranam, P. (2015). "Business groups in developing capital markets: Towards a complementarity perspective". Strategic Management Journal, 36(9), 1277-1296. https://doi.org/10.1002/smj.2287.

Choi, Y.R., Yoshikawa, T., Zahra, S.A. \& Han, B.H. (2014). "Market-oriented institutional change and R\&D investments: Do business groups enhance advantage?" Journal of World Business, 49(4), 466-475. https://doi.org/10.1016/j.jwb.2013.10.002.

Chuang, S.H. \& Lin, H.N. (2017). "Performance implications of information-value offering in e-service systems: Examining the resource-based perspective and innovation strategy". The Journal of Strategic Information Systems, 26(1), 22-38. https://doi.org/10.1016/j.jsis.2016.09.001.

Cuervo-Cazurra, A. (2006). "Business groups and their types". Asia Pacific Journal of Management, 23(4), 419-437. https://doi.org/10.1007/s10490-006-9012-5.

Duquesnois, F., Gurãu, C. \& Le Roy, F. (2010). "Wine producers' strategic response to a crisis situation". International Journal of Wine Business Research, 22(3), 251-268. https://doi.org/10.1108/17511061011075383.

Evaldo Fensterseifer, J. \& Rastoin, J. L. (2013). "Cluster resources and competitive advantage: A typology of potentially strategic wine cluster resources". International Journal of Wine Business Research, 25(4), 267-284. https://doi.org/10.1108/IJWBR-04-2011-0007. 
Fagerberg, J. (1987). “A technology gap approach to why growth rates differ". Research Policy, 16(2), 87-99. https://doi.org/10.1016/0048-7333(87)90025-4.

Fisman, R. \& Khanna, T. (2004). "Facilitating development: The role of business groups". World Development, 32(4), 609-628. https://doi.org/10.1016/j.worlddev.2003.08.012.

Galati, A., Crescimanno, M., Rossi, M., Farruggia, D. \& Tinervia, S. (2014). "The determinants affecting the internationalisation of the Italian SMEs producing sparkling wines: an empirical study on the RBV of the firms". International Journal of Globalisation and Small Business, 6(2), 100-118. https://doi.org/10.1504/IJGSB.2014.066463.

Gambardella, A. \& Giarratana, M.S. (2013). "General technological capabilities, product market fragmentation, and markets for technology". Research Policy, 42(2), 315-325. https://doi.org/10.1016/j.respol.2012.08.002.

Gil, A.J., García-Alcaraz, J.L. \& Mataveli, M. (2015). "The training demand in organizational changes processes in the Spanish wine sector". European Journal of Training and Development, 39(4), 315-331.

Granovetter, M. (1995). "Coase revisited: Business groups in the modern economy". Industrial and Corporate Change, 4(1), 93-130. https://doi.org/10.1093/icc/4.1.93.

Grant, R.M. (1996). "Toward a knowledge-based theory of the firm". Strategic Management Journal, 17(S2), 109-122. https://doi.org/10.1002/smj.4250171110.

Grant, R.M. (2010). Contemporary strategy analysis: Text and cases edition. Chichester: John Wiley \& Sons. Chichester.

Guillen, M.F. (2000). "Business groups in emerging economies: A resource-based view". Academy of Management Journal, 43(3), 362-380. https://doi.org/10.2307/1556400.

Gupta, S., Woodside, A., Dubelaar, C. \& Bradmore, D. (2009). "Diffusing knowledge-based core competencies for leveraging innovation strategies: Modelling outsourcing to knowledge process organizations (KPOs) in pharmaceutical networks". Industrial Marketing Management, 38(2), 219-227. https://doi.org/10.1016/j.indmarman.2008.12.010.

Hair, J.F., Black, W.C., Babin, B.J., Anderson, R.E. \& Tatham, R.L. (2009). Análise multivariada de dados. Porto Alegre: Bookman Editora.

Hammervoll, T., Mora, P. \& Toften, K. (2014). "The financial crisis and the wine industry: The performance of niche firms versus mass-market firms". Wine Economics and Policy, 3(2), 108-114. https://doi.org/10.1016/j.wep.2014.11.001.

Iacobucci, D. \& Rosa, P. (2005). "Growth, diversification, and business group formation in entrepreneurial firms". Small Business Economics, 25(1), 65-82. https://doi.org/10.1007/s11187-005-4258-8.

Iacobucci, D. \& Rosa, P. (2010). "The growth of business groups by habitual entrepreneurs: The role of entrepreneurial teams". Entrepreneurship Theory and Practice, 34(2), 351-377. https://doi.org/10.1111/j.1540-6520.2010.00378.x.

International Organisation of Vine and Wine (2016). World viticulture situation. Retrieved from http://www.oiv.int/public/medias/5029/world-vitiviniculturesituation-2016.pdf. (3/24/2017). 
Jensen, R. (2007). "The digital provide: Information (technology), market performance, and welfare in the South Indian fisheries sector". The Quarterly Journal of Economics, 879-924. https://doi.org/10.1162/qjec.122.3.879.

Jiménez, D.J. \& Sanz, R. (2006). “Innovación, aprendizaje organizativo y resultados empresariales: un estudio empírico". Cuadernos de Economía y Dirección de la Empresa, (29), 31-55.

Julien, P.A. (1995). "New technologies and technological information in small businesses". Journal of Business Venturing, 10(6), 459-475. https://doi.org/10.1016/0883-9026(95)00084-L.

Kazadi, K., Lievens, A. \& Mahr, D. (2016). "Stakeholder co-creation during the innovation process: Identifying capabilities for knowledge creation among multiple stakeholders". Journal of Business Research, 69(2), 525-540. https://doi.org/10.1016/j.jbusres.2015.05.009.

Khanna, T. \& Palepu, K. (2000). "The future of business groups in emerging markets: Long-run evidence from Chile". Academy of Management Journal, 43(3), 268-285.

Leff, N.H. (1978). "Industrial organization and entrepreneurship in the developing countries: The economic groups". Economic Development and Cultural Change, 26(4), 661-675.

Li, D.Y. \& Liu, J. (2014). "Dynamic capabilities, environmental dynamism, and competitive advantage: Evidence from China". Journal of Business Research, 67(1), 2793-2799. https://doi.org/10.1016/j.jbusres.2012.08.007.

MAGRAMA. (2016). Ministerio de Agricultura, Alimentación y Medio Ambiente (MAGRAMA). http://www.mapama.gob.es/es/alimentacion/temas/industriaagroalimentaria/ informeanualindustriaalimentaria2014-2016 tcm7-203254.pdf.

Mahmood, I. P., Zhu, H. \& Zaheer, A. (2017). "Centralization of intragroup equity ties and performance of business group affiliates". Strategic Management Journal, 38: 1082-1100. https://doi.org/10.1002/smj.2542.

Mamaqi, X., González Álvarez, M.A. \& Albisu Aguado, L.M. (2009). "La relación entre ventajas competitivas y resultados empresariales en la industria agroalimentaria aragonesa". Economía Agraria y Recursos Naturales, 9(2), 79-104.

Mithas, S., Ramasubbu, N. \& Sambamurthy, V. (2011). "How information management capability influences firm performance". MIS Quarterly, 35(1), 237.

Morrison, A. \& Rabellotti, R. (2017). "Gradual catch up and enduring leadership in the global wine industry". Research Policy, 46(2), 417-430. https://doi.org/10.1016/j.respol.2016.09.007.

Neill, S., Singh, G. \& Pathak, R.D. (2014). "Technology and marketing capabilities in a developing economic context: Assessing the resource-based view within a boundary condition". International Journal of Business and Economics, 13(1), 75-92.

Newton, S.K., Gilinsky, A. \& Jordan, D. (2015). "Differentiation strategies and winery financial performance: An empirical investigation". Wine Economics and Policy, 4(2), 88-97. https://doi.org/10.1016/j.wep.2015.10.001. 
Nietzsche, F. (2003). Beyond good and evil. Penguin. New York.

Ortega, M.J. (2010). "Competitive strategies and firm performance: Technological capabilities' moderating roles". Journal of Business Research, 63(12), 1273 1281. https://doi.org/10.1016/j.jbusres.2009.09.007.

Owens, I., Wilson, T.D. \& Abell, A. (1997). "Information and business performance: a study of information systems and services in high-performing companies". Journal of Librarianship and Information Science, 29(1), 19-28.

Porter, M.E. \& Strategy, C. (1980). Techniques for analyzing industries and competitors. Competitive Strategy. New York: FreePress.

Porter, M.E. (1985). Competitive advantage: creating and sustaining superior performance. New York: FreePress.

Rapp, A., Trainor, K.J. \& Agnihotri, R. (2010). "Performance implications of customer-linking capabilities: Examining the complementary role of customer orientation and CRM technology". Journal of Business Research, 63(11), 1229-1236. https://doi.org/10.1016/j.jbusres.2009.11.002.

Rivard, S., Raymond, L. \& Verreault, D. (2006). "Resource-based view and competitive strategy: An integrated model of the contribution of information technology to firm performance". The Journal of Strategic Information Systems, 15(1), 2950. https://doi.org/10.1016/j.jsis.2005.06.003.

Robinson, R.B., \& Pearce, J.A. (1988). "Planned patterns of strategic behavior and their relationship to business-unit performance". Strategic Management Journal, 9(1), 43-60.

Rubio Bañón, A. \& Aragón, A. (2002). "Factores explicativos del éxito competitivo. Un estudio empírico en la pyme". Cuadernos de Gestión, 2(1), 49-63.

Rubio Bañón, A. \& Aragón, A. (2009). “Recursos Críticos y Estrategia en la Pyme industrial”. Revista ICE Tribuna de Economía, 846, 193-212.

Rumelt, R.P (1987). "Toward a Strategic Theory of the Firm”. In Foss, N.J. (Ed.). Resources Firms and Strategic: A reader in the resource-based perspective (pp. 131-145). INew York: Oxford University Press.

Sellers-Rubio, R. (2010). "Evaluating the economic performance of Spanish wineries". International Journal of Wine Business Research, 22(1), 73-84. https://doi.org/10.1108/17511061011035215.

Simon-Elorz, K., Castillo-Valero, J.S. \& García-Cortijo, M.C. (2015). "Economic Performance and the Crisis: Strategies Adopted by the Wineries of Castilla-La Mancha (Spain)". Agribusiness, 31(1), 107-131. https://doi.org/10.1002/agr.21392.

Simón, F.G. \& Marqués, D.P. (2005). "Los patrones de comportamiento estratégico en el sector hotelero español: una validación del modelo de Robinson y Pearce". Investigaciones Europeas de Dirección y Economía de la Empresa, 11(2), 99-117.

Singh, D.A. \& Gaur, A.S. (2009). "Business group affiliation, firm governance, and firm performance: Evidence from China and India". Corporate Governance: An International Review, 17(4), 411-425. https://doi.org/10.1111/ j.1467-8683.2009.00750.x. 
Sistema de Análisis de Balances Ibéricos, SABI, 2016. Database. https://sabi. bvdinfo.com.

Song, M., Di Benedetto, C.A. \& Nason, R.W. (2007). "Capabilities and financial performance: The moderating effect of strategic type". Journal of the Academy of Marketing Science, 35(1), 18-34. https://doi.org/10.1007/s11747-006-0005-1.

Spanos, Y.E. \& Lioukas, S. (2001). "An examination into the causal logic of rent generation: Contrasting Porter's competitive strategy framework and the resource-based perspective". Strategic Management Journal, 22(10), 907-934. https://doi.org/10.1002/smj.174.

Stiglitz, J.E. (1975). "The theory of "screening", education, and the distribution of income". The American Economic Review, 65(3), 283-300.

Stiglitz, J. E. \& Greenwald, B.C. (2014). La creación de una sociedad del aprendizaje: Una nueva aproximación al crecimiento, el desarrollo y el progreso social. Madrid: La Esfera de los Libros.

Suárez, F.F. (1994). "La competitividad de las empresas, evolución, imperativos estratégicos y características de la organización exitosa de hoy”. Estudios Públicos, $54,151-174$.

Takata, H. (2016). "Effects of industry forces, market orientation, and marketing capabilities on business performance: An empirical analysis of Japanese manufacturers from 2009 to 2011". Journal of Business Research, 69(12), 5611-5619. https://doi.org/10.1016/j.jbusres.2016.03.068.

Teece, D.J., Pisano, G. \& Shuen, A. (1997). "Dynamic capabilities and strategic management”. Strategic Management Journal, 18(7), 509-533.

Tippins, M.J. \& Sohi, R.S. (2003). "IT competency and firm performance: is organizational learning a missing link?” Strategic Management Journal, 24(8), 745-761. https://doi.org/10.1002/smj.337.

Vázquez, A.M. (2011). “Competitividad e innovación en los sistemas vitivinícolas locales: el caso de la DO Rías Baixas" Cuadernos de Estudios Agroalimentarios, 2, 153-174. Available in: http://www.fundacioncajamar.es/capitulocompetitividad-e-innovacion-en-los-sistemas-vitivinicolas-locales-el-caso-de-lado-rias-baixas-42.html.

Welter, C., Bosse, D.A. \& Álvarez, S.A. (2013). “The interaction between managerial and technological capabilities as a determinant of company performance: An empirical study of biotech firms". International Journal of Management, 30(1), 272.

Zhang, L., Sjögren, H. \& Kishida, M. (2016). "The emergence and organizational persistence of business groups in China, Japan, and Sweden". Industrial and Corporate Change, 25(6), 885-902. https://doi.org/10.1093/icc/dtw006. 